\title{
PENINGKATAN KAPASITAS DAN EFISIENSI PRODUKSI MINUMAN KESEHATAN INSTAN DAN KEMASAN CUP
}

\author{
Increasing of Production Capacity and Efficiency of Instant and Cup Packaged \\ Health Drinks \\ Harijono dan Feronika Heppy Sriherfyna \\ Jurusan Teknologi Hasil Pertanian, Fakultas Teknologi Pertanian, Univ. Brawijaya \\ Jl. Veteran, Malang \\ Email: harijono_07@yahoo.com dan harijono@ub.ac.id
}

\begin{abstract}
Functional food industries have a promising prospect that this condition encourage some small medium enterprise (SME) food industries at Malang and Batu produce healthy beverages. Two of those SMEs are SME DIA that produces instant healthy drinks from ginger, tumeric, curcuma, and Aloe vera, and SME Bintang Putra Mandiri that produces curcuma extract drink in cup packaging. These SMEs had some problems that limit their production capacty. SME DIA had problems in medicinal herb extraction, mixing, and heating. SME Bintang Putra Mandiri had limited production capacity at extraction/boiling, settling, and packaging. The results of this program showed that mechanical technologies in instant drink production could reduce time for crystallization and increase production capacity from $10 \mathrm{~kg}$ herbs/day into 30 $\mathrm{kg}$ for 3 hour mixing. Shredder and mechanical pressure could also increase extraction efficiency. Mechanical technology in curcuma extract drink production could increase production capacity from 20 L per batch into 80-200 L/batch. Storage tank also could increase storage and sedimentation efficiency. This process was also more sterile and the capacity of storage was higher. Semi automatic cup sealer also increased efficiency and packaging capacity from 300 cup into 1500 cup per day.
\end{abstract}

Keywords: crystallization, extraction, instant drink, production efficiency, packaging, sterilization.

\begin{abstract}
ABSTRAK
Industri yang memproduksi pangan fungsional (makanan dan minuman) untuk kesehatan mempunyai prospek yang menjanjikan. Kondisi ini mendorong beberapa usaha kecil mikro di Kota Batu dan Malang memproduksi dan memasarkan minuman untuk kesehatan. Usaha kecil mikro (UKM) yang memproduksi minuman fungsional kesehatan adalah UKM DIA yang mengolah minuman kesehatan instan (jahe, kunyit, temulawak, mengkudu, dan lidah buaya) serta UKM Bintang Putra Mandiri yang memproduksi minuman sari temulawak dalam kemasan cup. Permasalahan yang dihadapi oleh UKM DIA pada proses produksi kesehatan instan adalah pada proses pemerasan empon-empon, pemblenderan, pengadukan dan pemasakan, serta pengayakan produk jadi. Permasalahan utama yang dihadapi mitra Bintang Putra Mandiri adalah kapasitas produksi dan efisiensi proses yang rendah, pada proses perebusan/ekstraksi, pengendapan, dan pengemasan. Hasil kegiatan menunjukkan bahwa alih teknologi mekanis untuk produksi minuman kesehatan instan di UKM DIA telah mereduksi waktu yang dibutuhkan untuk pengadukan atau kristalisasi dari $10 \mathrm{~kg}$ empon-empon per hari menjadi $30 \mathrm{~kg}$ empon-empon untuk 1 jam pengadukan. Penggunaan pemarut empon-empon dan pengepres mekanis pada proses ekstraksi sari empon-empon telah meningkatkan efisiens ekstraksi. Alih teknologi pembuatan minuman sari temulawak dalam kemasan cup meliputi ekstraksi, penyaringan, dan
\end{abstract}


pengemasan telah meningkatkan efisiensi dan kapasitas produksi mitra UKM Bintang Putra Mandiri. Proses ektraksi temulawak meningkat dari kapasitas $20 \mathrm{~L}$ per batch menjadi 80-100 L. Adanya tanki penyimpanan menyebabkan proses penyimpanan dan pengendapan menjadi lebih steril dan dapat dilakukan dalam jumlah besar. Penggunaan pengemas cup semi otomatis meningkatkan kapasitas dan efisiensi pengemasan mitra dari kapasitas 300 cup per hari menjadi 1500 cup.

Kata kunci: efisiensi produksi, ekstraksi, instan, kapasitas produksi, kristalisasi, pengemasan, sterilisasi

\section{PENDAHULUAN}

Prevalensi penyakit degeneratif saat ini semakin meningkat dari tahun ketahun. Berdasarkan hasil pengukuran tekanan darah, prevalensi hipertensi pada penduduk umur 18 tahun keatas di Indonesia adalah sebesar $31,7 \%$, prevalensi stroke di Indonesia sebesar $8,3 \%$, prevalensi penyakit jantung di Indonesia adalah 7,2\% dan prevalensi DM di Indonesia adalah $1,1 \%$. Prevalesnsi penyakit degeneratif tampak meningkat sesuai peningkatan umur responden (Riskesdas, 2007). Hal tersebut menyebabkan pangan yang mempunyai fungsi terhadap kesehatan atau sering disebut pangan fungsional menjadi pola konsumsi masyarakat. Hal ini menyebabkan industri yang memproduksi pangan fungsional (makanan dan minuman) untuk kesehatan mempunyai prospek yang menjanjikan. Pangan fungsional dapat diolah dari bahan pangan yang mempunyai khasiat terhadap kesehatan seperti jahe (Rehman et al., 2003, Brown et al., 2009), kunyit, temulawak (Venukumar dan Latha, 2002; Tohda et al., 2006), mengkudu, dan lidah buaya.

Kondisi ini mendorong beberapa usaha kecil mikro di Kota Batu dan Malang memproduksi dan memasarkan minuman untuk kesehatan. Salah satu UKM tersebut adalah UKM DIA. Produk yang dihasilkan oleh UKM "DIA" adalah minuman kesehatan instan berbahan baku emponempon (jahe, kunyit putih, kunyit asam, temulawak, beras kencur), mengkudu, dan lidah buaya. Walaupun kapasitas produksi mitra cukup besar, sayangnya proses pengolahan yang dilakukan masih manual terutama pada proses kristalisasi yang merupakan titik kritis proses pengolahan minuman instan. Hal ini menyebabkan mitra UKM "DIA" tidak bisa meningkatkan kapasitas produksinya.

Usaha kecil mikro (UKM) lain yang memproduksi minuman kesehatan adalah UKM Bintang Putra Mandiri. Produk yang dihasilkan berupa minuman sari temulawak dalam kemasan cup ukuran 120.

Proses pengolahan minuman sari temulawak dilakukan melalui proses ekstraksi temulawak, kunyit, dan kayu manis kering. Ekstraksi dilakukan dengan cara perebusan selama 1 jam dalam kapasitas panci berukuran 10 dan 15 liter. Dalam satu hari, produksi sari temulawak adalah 10-15 boks atau 40-60 L, sehingga proses perebusan dilakukan berulang kali. Setelah ekstraksi, sari temulawak didinginkan 3-4 jam kemudian disaring menggunakan kain saring rangkap 4 untuk menghilangkan endapan. Sebenarnya mitra sudah mempunyai filter sistem pompa akan tetapi belum digunakan karena dalam satu kali pemompaan kapasitas harus banyak (sekitar 100 L) dan mitra belum mempunyai storage tank untuk penyimpanan sementara sari temulawak. Kapasitas perebusan yang kecil menjadi masalah bagi mitra selain tidak adanya tangki penyimpanan.

Permasalahan lain yang dihadapi mitra adalah proses pengemasan yang menggunakan manual cup sealer berukuran kecil, sehingga untuk produksi 10-15 dus minuman sari temulawak sehari memerlukan pengemasan sehari penuh (8 jam kerja). Masalah lain di mitra adalah 
kapasitas sterilsiasi minuman sari temulawak dalam cup yang rendah menggunakan panci berukuran 10-15 L sehingga proses sterilisasi harus dilakukan berulang kali. Peningkatan kapasitas dan efisiensi produksi menjadi permasalahan yang dihadapi mitra. Peningkatan kapasitas dan efisiensi produksi dapat dicapai melalui alih teknologi mekanis untuk tahapan proses yang selama ini dilakukan secara manual.

\section{METODE PELAKSANAAN}

Pelaksanaan kegiatan IbM ini ditujukan untuk menyelesaikan permasalahan yang dihadapi oleh kedua mitra yaitu Mitra 1 - UKM DIA dan Mitra 2 - UKM Bintang Putra Mandiri. Metode pelaksanaannya adalah sebagai berikut:

\section{Peningkatan efisiensi dan kapasitas produksi minuman kesehatan instan di Mitra 1 - UKM "DIA"}

Alih teknologi ekstraksi dan pengadukan pada proses produksi minuman instan kesehatan, dan peningkatan kapasitas blender pada pengolahan minuman instan lidah buaya dapat mempersingkat proses pengolahan minuman kesehatan instan sehingga dapat meningkatkan kapasitas produksi.

\section{Peningkatan kapasitas dan efisiensi produksi minuman sari temulawak di Mitra 2 - UKM Bintang Putra Mandiri}

Peningkatan kapasitas dan efisiensi produksi melalui peningkatan kapasitas ekstraksi menggunakan panci stainless steel kapasitas $100 \mathrm{~L}$ dan kompor gas industri untuk mengimbangi peningkatan kapasitas perebusan. Untuk meningkatkan efisiensi penyaringan, diperlukan tangki penyimpanan kapasitas $200 \mathrm{~L}$ sehingga mitra bisa menggunakan pompa filter yang selama ini ada tetapi belum bisa digunakan karena kapasitas penyimpanan hanya di panci aluminum ukuran 10-15 L .
Penggunaan pengemas cup semi otomatis diharapkan dapat meningkatkan kapasitas pengemasan mitra dari 10-15 dus atau 320-480 cup/hari menjadi 1000-1500 cup per hari. Peningkatan kapasitas ekstraksi dan pengemasan harus diimbangi dengan peningkatan kapasitas sterilisasi yang bisa menggunakan panci perebus sainless steel yang digunakan untuk proses ekstraksi.

\section{HASIL DAN PEMBAHASAN}

\section{Peningkatan efisiensi dan kapasitas produksi minuman kesehatan instan di Mitra 1 - UKM "DIA"}

Tahap awal pengolahan minuman kesehatan instan dari empon-empon adalah pencucian yang saat ini masih dilakukan secara manual. Empon-empon setelah dicuci kemudian diperas untuk diambil sarinya. Alih teknologi ekstraksi pada awalnya direncanakan menggunakan alat juicer dengan kapasitas 80-100 kg/jam. Akan tetapi juicer yang tercantum di proposal ternyata tidak sesuai dengan empon-empon karena tekstur empon-empon yang keras dan juicer tersebut lebih sesuai untuk buah-buahan. Untuk memecahkan permasalahan tersebut, dari hasil diskusi dengan mitra, mitra mengajukan alternatif pemarut dan pemeras/pengepres.

Proses pemerasan dengan cara pemarutan empon-empon menggunakan mesin pemarut (Gambar 1a). Pada awalnya, Mitra UKM "DIA" melakukan pembuatan sari empon-empon dengan cara diblender menggunakan blender ukuran rumah tangga, kemudian hasil bubur empon-empon yang diperoleh diperas secara manual menggunakan kain saring. Selanjutnya sari empon-empon tersebut diendapkan untuk menghilangkan pati. Pati harus dihilangkan karena akan menghambat proses kristalisasi. Adanya pati menyebabkan sari emponempon membentuk gel. 


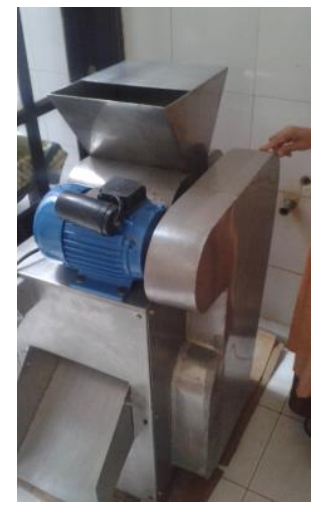

(a)

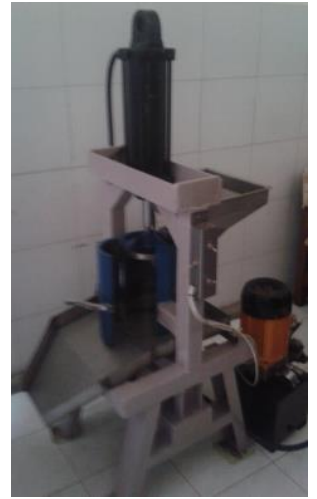

(b)

Gambar 1. Mesin pemarut empon-empon (a) dan pengepres (b)

\begin{abstract}
Untuk meningkatkan efisiensi produksi dan meningkatkan kapasitas produksi, mitra memperbaiki proses pembuatan sari empon-empon dari semi manual menajdi mekanis menggunakan mesin pemarut. Mesin pemarut tersebut dibeli sendiri oleh Mitra. Untuk pengepresan sari empon-empon yang bertujuan memisahkan sari dengan ampas, peningkatan efisiensi dan kapasitas dilakukan dengan menggunakan mesin pengepres mekanis (Gambar 1b). Mesin pengeres ini dibantu melalui program IbM ini.
\end{abstract}

Dengan adanya kedua alat mekanis tersebut, proses pembuatan sari emponempon meningkat dari $2 \mathrm{~kg}$ empon-empon per 2 jam menjadi 80-100 kg empon-empon untuk 1 jam. Peningkatan ini mengefisienkan proses pembuatan minuman instan dan mengurangi tenaga manusia yang digunakan. Peningkatan efisiensi dan kapasitas pemerasan sari empon-empon menjadi penting mengingat proses selanjutnya setelah pemerasan adalah pemasakan/kristalisasi yang ditingkatkan dengan bantuan mesin pengaduk mekanis.

Untuk meningkatkan kapasitas dan efisiensi produksi Mitra UKM DIA, titik kritis pada proses pengolahan minuman kesehatan instan adalah pengadukan. Selama ini mitra melalukan pengadukan secara manual menggunakan wajan ukuran besar. Dalam satu kali pengadukan dengan kapasitas empon-empon $10 \mathrm{~kg}$ dibutuhkan waktu 8 jam. Alih teknologi mekanis pengadukan sari empon-empon disertai dengan pemasakan untuk kristalisasi dilakukan dengan menggunakan alat seperti dapat dilihat pada Gambar 2.

Tabel 1. Perbandingan efisiensi dan kapasitas produksi sebelum dan setelah alih teknologi melalui Program IbM

\begin{tabular}{|c|c|c|c|c|c|}
\hline \multirow[t]{2}{*}{ No. } & \multirow[t]{2}{*}{ Tahapan } & \multicolumn{2}{|c|}{ Kondisi Sebelum Program } & \multicolumn{2}{|c|}{ Kondisi Setelah Program } \\
\hline & & $\begin{array}{l}\text { Kapasitas per } \\
\text { Batch }\end{array}$ & $\begin{array}{c}\text { Lama } \\
\text { Proses }\end{array}$ & $\begin{array}{l}\text { Kapasitas per } \\
\text { Batch }\end{array}$ & $\begin{array}{c}\text { Lama } \\
\text { Proses }\end{array}$ \\
\hline 1. & Pemerasan/Ekstraksi & $\begin{array}{l}2 \mathrm{~kg} \text { empon- } \\
\text { empon }\end{array}$ & 2 jam & $80-100 \mathrm{~kg}$ & 1 jam \\
\hline 2. & Pemasakan/Kristalisasi & $\begin{array}{l}2 \mathrm{~kg} \text { empon- } \\
\text { empon } \\
10 \mathrm{~kg} \text { empon- } \\
\text { empon }\end{array}$ & $\begin{array}{l}40 \text { menit } \\
8 \text { jam }\end{array}$ & $\begin{array}{l}\text { 50-75 liter atau } \\
30 \mathrm{~kg} \text { gula pasir } \\
\text { atau } 30 \mathrm{~kg} \\
\text { empon-empon }\end{array}$ & $1 \mathrm{jam}$ \\
\hline
\end{tabular}




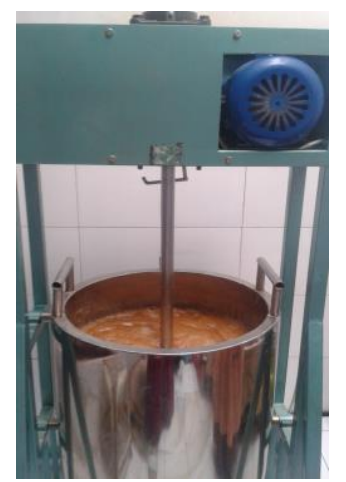

Gambar 2. Pengaduk mekanis untuk kristalisasi minuman instan kesehatan

Kapasitas mesin pengaduk adalah 30 $\mathrm{kg}$ gul pasir untuk 1 batch proses. Gula pasir sebanyak $30 \mathrm{~kg}$ tersebut untuk $30 \mathrm{~kg}$ empon-empon. Dengan adanya adalah ini, mitra dapat mengefisienkan waktu produksi dan meningkatkan kapasitas produksi seperti tercantum pada Tabel 1. Selain itu tenaga kerja yang biasa mengerjakan proses pemasakan dialihkan untuk proses pengemasan.

Setelah proses pemasakan selesai, kemudian dilakukan pengadukan dalam untuk mendapatkan kristal-kristal yang tidak menggumpal dan diperoleh butiran halus minuman instan. Selanjutnya minuman instan yang sudah jadi dismpan terlebih dahulu di dalam toples plastik sebelum keesokan harinya dilakukan pengemasan. Mitra juga menjual produknya dalam bentuk curah, selain dalam bentuk aneka ragam kemasan.

\section{Peningkatan kapasitas dan efisiensi produksi minuman sari temulawak di Mitra 2 - UKM Bintang Putra Mandiri}

UKM Bintang Putra Mandiri mempunyai permasalahan proses perebusan (ekstraksi) sari temulawak yang lama akibat kapasitas panci perebus yang kecil, pengendapan yang lama dan berkapasitas kecil, proses penyaringan yang masih manual, serta pengemasan yang lama akibat alat yang digunakan berkapasitas rendah.

Untuk mengatasi permasalahan yang ada di mitra, mitra mengharapkan peningkatan kapasitas dan efisiensi produksi melalui peningkatan kapasitas ekstraksi menggunakan panci stainless steel kapasitas 100 L dan kompor gas industri untuk mengimbangi peningkatan kapasitas perebusan. Untuk meningkatkan efisiensi penyaringan, diperlukan tangki penyimpanan kapasitas $200 \mathrm{~L}$ sehingga mitra bisa menggunakan pompa filter yang selama ini ada tetapi belum bisa digunakan karena kapasitas penyimpanan hanya di panci aluminum ukuran 10-15 L .

Bantuan tanki penyimpanan sangat dibutuhkan oleh Mitra 2. Dengan adanya tanki penyimpanan, mitra dapat mendinginkan produk sekaligus mengendapkannya. Tanki ini juga dapat dijaga kesterilannya karena merupakan tanki tertutup dengan keran di bagian bawah untuk mengeluarkan produk (Gambar 3).
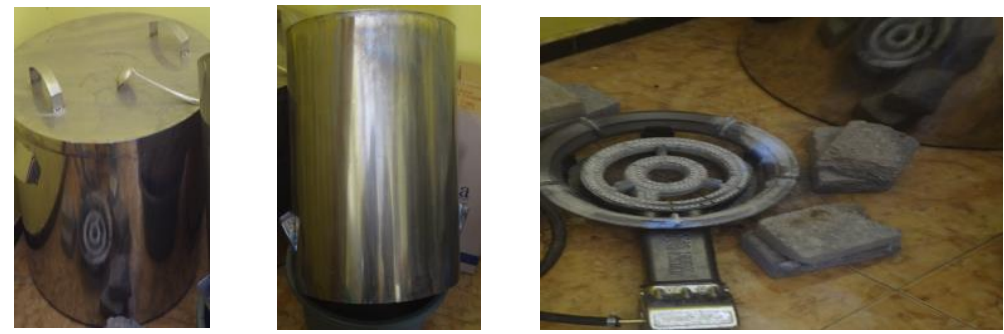

Gambar 3. Tanki penyimpanan (a), panci perebus (b), dan kompor industri (c) 
Tabel 2. Perbandingan efisiensi dan kapasitas produksi sebelum dan setelah alih teknologi melalui Program IbM

\begin{tabular}{|c|c|c|c|c|c|}
\hline \multirow[t]{2}{*}{ No. } & \multirow[t]{2}{*}{ Tahapan } & \multicolumn{2}{|c|}{ Kondisi Sebelum Program } & \multicolumn{2}{|c|}{ Kondisi Setelah Program } \\
\hline & & $\begin{array}{c}\text { Kapasitas per } \\
\text { Batch }\end{array}$ & $\begin{array}{l}\text { Lama } \\
\text { Proses }\end{array}$ & $\begin{array}{c}\text { Kapasitas per } \\
\text { Batch }\end{array}$ & $\begin{array}{l}\text { Lama } \\
\text { Proses }\end{array}$ \\
\hline 1. & Ekstraksi & $10-15 \mathrm{~L}$ & 1 jam & $100 \mathrm{~L}$ & 1 jam \\
\hline 2. & $\begin{array}{l}\text { Pengendapan/ } \\
\text { penyimpanan }\end{array}$ & $10-15 \mathrm{~L}$ & 3-4 jam & $200 \mathrm{~L}$ & 3-4 jam \\
\hline 3. & Pengemasan & 300-500 сир & 1 hari & 1000-1500 сир & 1 hari \\
\hline 4. & Sterilisasi & $10-15 \mathrm{~L}$ & 30 menit & $100 \mathrm{~L}$ & 30 menit \\
\hline
\end{tabular}

Panci perebus kapasitas $100 \mathrm{~L}$ dan kompor cor industri dapat meningkatkan kapasitas produksi Mitra, Selama ini mitra menggunakan panci kecil ukran 20 L dengan kompor yang digunakan adalah kompor gas rumah tangga. Akibatnya proses perebusan dilakukan berulang kali. Adanya alat ini membantu mitra untuk membuat produk dalam jumlah besar. Alat ini dapat meningkatkan kapasitas produksi mitra dari $15 \mathrm{~L}$ per jam menjadi $100 \mathrm{~L}$ per jam. Tanki juga dapat mengefisienkan penyimpanan dari 15 L menjadi 200 L sekali penyimpanan (Tabel 2).

Peningkatan kapasitas pengemasan penting dilakukan di mitra untuk mengatasi permasalahan selama ini yang hanya menggunakan manual cup sealer. Penggunaan pengemas cup semi otomatis (Gambar 4) diharapkan dapat meningkatkan kapasitas pengemasan mitra dari 10-15 dus atau 320-480 cup/hari menjadi 1000-1500 cup per hari. Peningkatan kapasitas ekstraksi dan pengemasan harus diimbangi dengan peningkatan kapasitas sterilisasi yang bisa menggunakan panci perebus sainless steel yang digunakan untuk proses ekstraksi.

Pengemas cup semi otomatis menggunakan sistem pengisian cup yang otomatis sehingga proses pengemasan bisa lebih cepat. Pengemas cup sealer juga dilengkapi dengan sistem sterilisasi dingin dengan menggunakan kejut listrik (PEF, Pulsed Electrical Field). Dengan metode ini mikrobia di dalam sari temulawak dapat diinaktivasi dengan pemanasan yang rendah. Alat PEF ini dibutuhkan mitra untuk pengembangan minuman beras kencur.

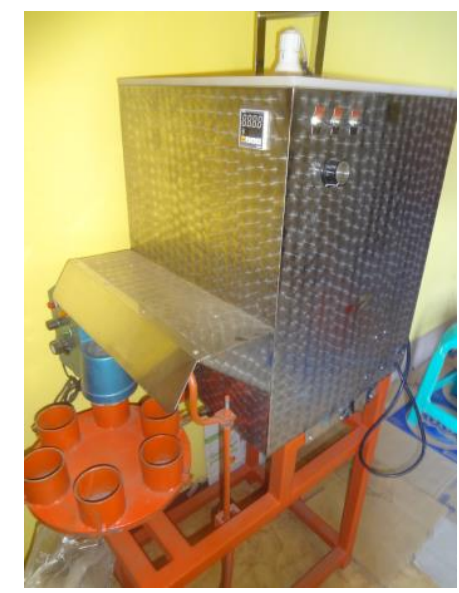

Gambar 4. Cup sealer semi otomatis yang dilengkapi dengan sterilisasi dingin PEF (Pulsed Electrical Field) di Mitra 2 


\section{KESIMPULAN}

Kedua

mitra

mengimplementasikan

sudah

kapasitas dan efisiensi produksi dengan alih teknologi mekanis. Kapasitas dan efisiensi produksi mitra yang memproduksi minuman kesehatan instan meningkat pada proses ekstraksi dan pengadukan/kristalisasi. Kapasitas dan efisiensi produksi mitra minuman kesehatan kemasan meningkat pada proses ekstraksi, sterilisasi, dan pengemasan.

\section{UCAPAN TERIMA KASIH}

Penulis mengucapak terima kasih yang sebesar-besarnya kepada Kementerian Riset, Teknologi, dan Pendidikan Tinggi atas pendanaan Iptek bagi Masyarakat tahun 2016, serta LPPM Universitas Brawijaya yang telah mendukung penuh pelaksanaan kegiatan ini.

\section{DAFTAR PUSTAKA}

Brown, A.C., C. Shah, J. Liu, J.T. H. Pham, J.G. Zhang and M.R. Jadus. 2009. Ginger's (Zingiber officinale Roscoe) Inhibition of Rat Colonic Adenocarcinoma Cells Proliferation and Angiogenesis In Vitro. Phytother.
Res. 23, 640-645. DOI: 10.1002/Ptr.2677.

Rehman, Z.U., A.M. Salariya, and F. Habib. 2003. Antioxidant Activity of Ginger Extract in Sunflower Oil. J. Sci. Food Agric. 83:624-629. DOI: $10.1002 / \mathrm{J}$ sfa. 1318

Riskesdas. 2007. Riset Kesehatan Dasar. Balai Penelitian dan Pengembangan Kesehatan, Kementerian Kesehatan Republik Indonesia.

Tohda, N. Nakayama, F. Hatanaka, and K. Komatsu. 2006. Comparison of AntiInflammatory Activities of Six Curcuma Rhizomes: A Possible Curcuminoid-Independent Pathway Mediated by Curcuma phaeocaulis Extract. eCam 1-6. Doi:10.1093/Ecam/Nel008.

Venukumar, M.R. and M.S. Latha. 2002. Hepatoprotective Effect of The Methanolic Extract of Curculigoorchioides In CCl4 -Treated Male Rats. Indian Journal of Pharmacology 34: 269-275. 